\title{
Effect of Titanium Powder Loading in Gas Diffusion Layer of a Polymer Electrolyte
}

\section{Unitized Reversible Fuel Cell}

Chul Min Hwang a, Masayoshi Ishida a, Hiroshi Ito b*, Tetsuhiko Maeda b, Akihiro Nakano ${ }^{b}$, Atsushi Kato ${ }^{c}$, Tetsuya Yoshida ${ }^{d}$

a Department of Engineering Mechanics and Energy, University of Tsukuba, 1-1-1

Tennoudai, Tsukuba 305-8573, Japan

b Energy Technology Research Institute, National Institute of Advanced Industrial Science and Technology (AIST), 1-2-1 Namiki, Tsukuba 305-8564, Japan

c Takasago Thermal Engineering Co., Ltd., 3150 Iiyama, Atsugi 243-0213, Japan

d Daiki Ataka Engineering Co., Ltd., 11 Shintoyofuta, Kashiwa 277-8515, Japan

* Corresponding author, E-mail: ito.h@aist.go.jp

Tel: +81-29-861-7262, Fax: +81-29-851-7523

\begin{abstract}
Polymer electrolyte-based unitized reversible fuel cells (URFCs) can be operated either as an electrolyzer to split water into hydrogen and oxygen using electric power or as a fuel cell to supply electric power when fed hydrogen and oxygen or air. In a
\end{abstract}


URFC, titanium (Ti)-felt is used as a gas diffusion layer (GDL) in the oxygen electrode and typical carbon paper is used as a GDL in the hydrogen electrode. Here, first, Ti-powder was loaded into the Ti-felt GDL in URFCs to produce an effective pore distribution for water management in the membrane. Then, the effect of this Ti-powder loading on the cell performance was examined for both fuel cell and electrolysis operations. Experimental results revealed that the Ti-powder loading significantly improved the fuel cell performance under fully humidified conditions (relative humidity $(\mathrm{RH})=100 \%$, but not under relatively dry conditions $(\mathrm{RH}=66 \%)$. In contrast, the Ti-powder loading had no effect on the electrolysis performance.

Key words: proton exchange membrane; reversible fuel cell; gas diffusion layer; water management 


\section{Introduction}

Polymer electrolyte-based unitized reversible fuel cells (URFCs) are electrochemical cells that can operate either as a fuel cell or electrolyzer in a single unitized device. A system containing a URFC and a hydrogen storage unit is therefore a promising method for long-term energy storage, and due to low self-discharge, for back-up power instead of a secondary battery [1, 2]. Studies have evaluated URFCs with electro-catalysts [3-9], gas diffusion layers (GDLs) [10-11] and bipolar plates [12] for the oxygen-side.

A conventional oxygen-electrode GDL plays a crucial role in a proton exchange membrane fuel cell (PEMFC) by providing the primary water removal route from the cathode catalyst layer to the flow channel and by allowing reactant gas transport to the catalyst layer. Thus, in the development of PEMFCs, many studies have focused on improving the transport of produced water and supplied oxygen through the oxygen-electrode GDL [13-20]. To facilitate the removal of produced water from the active area of catalyst site, a hydrophobic microporous layer (MPL) is generally coated onto a gas diffusion backing (GDB), which is typically bare carbon paper. The MPL is usually a mixture of fine carbon particles and a hydrophobic agent and is then coated 
onto the GDB. In this case, the GDL is composed of GDB and MPL. The influence of the MPL components and properties, especially pore size distribution, on PEMFC performance have been investigated by using numerical simulation [21-24] and experimental analysis [25-39]. It is generally accepted that the MPL improves both water management and mass transport, by preventing rapid drying of the PEM at lower current density and by preventing electrode flooding at higher current densities. Several hypotheses about the role of an MPL have been suggested. For example, Weber and Newman [40] developed an analytical model to examine the effect of wettability of the diffusion media on water management, and confirmed an increase in fuel cell performance due to an MPL. They hypothesized that a capillary barrier acts as a valve to repel water from the oxygen-electrode GDL and to accelerate back diffusion of water from the cathode to the anode through the membrane. Wang et al. [41] developed a novel GDL with a MPL composed of a composite carbon black consisting of 20 wt.\% Black Pearls 2000 and 80 wt.\% Acetylene Black carbon. They classified the pores of GDL (including the MPL) into three categories: macro-pores with pore diameter over $7 \mu \mathrm{m}$, meso-pores from 0.05 to $7 \mu \mathrm{m}$, and micro-pores below $0.05 \mu \mathrm{m}$. They also pointed out that in hydrophobic meso-pores, liquid water does not easily penetrate into the pore because it needs to overcome the surface energy. Consequently, hydrophobic meso-pores 
are dry (i.e., "open"), and thus can act as a gas transport path. Gostick et al. [42] measured the water saturation and associated capillary pressure at the point of water breakthrough in GDL samples with and without an MPL. Their findings suggest that the MPL contributes to lower water saturation in GDL when the water breaks through the GDL.

The GDL of an URFC also plays the role of current collector in a PEM electrolyzer. To achieve stable electrical conductance and produced gas transport, this GDL is typically made of sintered porous metal, expanded metal mesh, or metal felt. Carbon paper or carbon cloth cannot be used in the GDL for an oxygen electrode because carbon materials tend to corrode at high potential during electrolysis. Grigoriev et al. [43] used a plate of sintered titanium powder as the GDL of electrolyzer and reported that the optimal pore size of a GDL in a PEM electrolyzer for current and mass transport is $12-13 \mu \mathrm{m}$. A titanium-felt has been used as the GDL of PEM electrolyzer and URFC by our group [44-45]. Ito et al. [44] investigated the effect of the flow characteristics on electrolysis performance and pressure drop, and reported that when the two-phase flow of the circulating water at the anode is either slug of annular, mass transport of water for the anode reaction is degraded at high current density. Our previous study of URFCs [45] revealed that electrolysis performance is not noticeably 
affected by a change in either the PTFE content in the GDL or porosity of the GDL, when the pore diameter of the oxygen-electrode GDL is less than about $50 \mu \mathrm{m}$.

The oxygen-electrode GDLs of a URFC play an important role in the water management, similar to the role in PEMFC and PEM electrolyzers. Despite this important role, the relation between this GDL in URFCs and water management has only recently been actively studied. In our previous work [45], titanium (Ti)-felt (nonwoven fabric) GDB without MPL was used as the GDL at the oxygen electrode to evaluate the effect of the properties of Ti-felt GDLs on URFC performance. Our results revealed that the pore size distribution (ratio of mean pore size and maximum pore size) of GDL is highly related with improving fuel cell performance, and mean pore size of GDL is important for electrolysis performance. However, all of the tested URFC cells with different characteristic Ti-felt GDLs showed a rapid decrease in fuel cell performance at fully wet conditions (relative humidity $(\mathrm{RH})=100 \%$ ) due to severer water flooding.

From the viewpoint of membrane durability, the cell operation under full humidification conditions (i.e., $\mathrm{RH}=100 \%$ ) is the best choice for commercial systems of URFC, because low RH operation (i.e., inadequate humidification) accelerates cell failure through membrane degradation [46]. However, as mentioned above, water 
management under full humidification conditions is difficult. Based on reports that the presence of an MPL could prevent flooding and thus improve PEMFC performance [20-39], modification of pore size distribution by MPL coating might improve URFC performance under fully wet condition.

In this study, fine Ti-powders were loaded onto Ti-felt GDB to modify the pore size distribution. The purpose of our present work was to verify the effect of the modified pore structure of Ti-felt GDL on the water management in the oxygen electrode of a URFC during fuel cell and electrolyzer operations. Ti-felt GDB with different amounts of Ti-powder loading were prepared as the oxygen electrode GDL, and the effect of the amount of Ti-powder loading on both the fuel cell and electrolyzer performance of a URFC was investigated.

\section{Experiments}

The single cell with $27 \mathrm{~cm}^{2}$ active area used here is identical with that described in our previous work [45]. The bipolar plate for the oxygen side (cathode for fuel cell mode) was made of titanium, and that for the hydrogen side (anode for fuel cell mode) was carbon. A membrane electrode assembly (MEA, developed through collaboration between Takasago Thermal Engineering Co. and Daiki Ataka Engineering Co.) was 
placed between the flow fields of both bipolar plates. In the MEA, iridium oxide $\left(\mathrm{IrO}_{2}\right)$ and platinum $(\mathrm{Pt})$ mixed-electrocatalyst was used for the oxygen electrode, and $\mathrm{Pt}$ catalyst for the hydrogen electrode. These catalytic electrodes were hot pressed to both surfaces of the PEM (Nafion 115). In all experiments in this work, carbon-paper gas diffusion backing (GDB) (Toray 090, porosity 78\%) treated with 10 wt.\% PTFE emulsion was used for the hydrogen-electrode side GDL and had a PTFE loading of about 14 wt.\% (69 $\mathrm{mg} / \mathrm{cm}^{3}$ ), and Ti-felt GDB (Bekinit) was used for the oxygen-electrode side GDL. Both substrates for the carbon paper and Ti-felt were approximately $300 \mu \mathrm{m}$ thick. Table 1 lists the specifications of GDL at the oxygen electrode used for URFC performance tests.

Three different sets of cells with Ti-felt GDL were prepared; U1, which had no PTFE or Ti-powder loading, U2 and U3, which had PTFE loading, and M1, M2, and M3, which had both PTFE and Ti-powder loading. The U1 cells were prepared in which "standard" Ti-felt GDL were not loaded with PTFE, and the porosity $(\varepsilon)$ and fiber diameter $(\phi)$ of the substrates were $75 \%$ and $20 \mu \mathrm{m}$, respectively. The U2 and U3 cells were prepared loading PTFE onto bare Ti-felt GDB at 69 and $148 \mathrm{mg} / \mathrm{cm}^{3}$, respectively. The M1, M2, and M3 cells samples were prepared as follows. First, Ti powder (Toho Titanium; average diameter of about $20 \mu \mathrm{m})$ was mixed with a dispersion agent $(0.1 \mathrm{~g})$ 
and deionized water ( 80 wt.\% of total slurry) by mechanical stirring. Then, PTFE was added as a binder material, at a $99: 1 \mathrm{wt} . \%$ ratio of Ti powder to polymer binder in the slurry. Next, the slurry was applied to bare Ti-felt GDB (the same substrates used in U1, namely, $\phi=20 \mu \mathrm{m}, \varepsilon=0.75$ and without PTFE loading) using a screen printing technique. For comparison purposes, different loading amount of Ti powder on the GDB were evaluated, namely, 110, 200 and $300 \mathrm{mg} / \mathrm{cm}^{3}$ based on outer geometry of GDB. Finally, the Ti-felt GDBs loaded with Ti powder were dried at $180^{\circ} \mathrm{C}$ for 30 minutes and then sintered at $360^{\circ} \mathrm{C}$ in vacuum condition for 1 hour. Note that Ti-powder loading includes a small amount of PTFE loading (as shown in Table 1), because the slurry contained PTFE.

The gas and liquid supply lines for the fuel cell mode and electrolysis mode of the URFC were separate, but also were connected at the inlet and outlet of the cell at both sides of the electrodes via switching valves. Fuel cell performance tests were performed by using a station specifically equipped for the fuel cell mode (PEMTEST8900, Toyo), namely, with a temperature controller for the cell and with a gas supply unit that included mass flow meters and humidifiers. The cell temperature $\left(T_{\text {cell }}\right)$ was kept constant at $80^{\circ} \mathrm{C}$ by electric heaters on both cover-plates and was controlled by the station during both the fuel cell and electrolysis modes. Air was used as an oxidant 
during the fuel cell mode. The stoichiometric ratio of the supplied pure hydrogen and oxygen in the air was kept at 1.43 and 2.50, respectively, and the humidification temperature $\left(T_{\text {fuel }}\right)$ of both reactant gases were changed arbitrarily but were always the same for a given test. The electric load (890CL, Scribner) was controlled by the station and used in measuring the current-voltage $(i-V)$ characteristics of the fuel cell. The cell resistance $\left(R_{\text {cell }}\right)$ was measured using a frequency response analyzer (FRA) (1255B, Solartron) and the load. During the electrolysis mode, water in the cell was circulated by using an accumulator, pump, preheating tank, flow meter, and flow control valve. De-ionized liquid water supplied to the cell was heated to the same temperature as the cell by a preheating tank. Theoretically, water must be supplied only to the oxygen electrode side, because water molecules move to the hydrogen electrode with protons during electrolysis. In our experiments, however, water was circulated at a flow rate of $25 \mathrm{ml} / \mathrm{min}$ at both sides of the electrodes to prevent membrane dry-out caused by lack of water. Two-phase flow of gas and liquid was released from the exit of the cell at both electrodes, and the produced gas $\left(\mathrm{H}_{2}\right.$ and $\left.\mathrm{O}_{2}\right)$ was separated from liquid water at the respective accumulators. DC power for the electrolysis was supplied and controlled by a power supply (PAN16, Kikusui). Cell voltage was measured at each i. Pore size distribution of each substrate was measured using a mercury intrusion porosimeter 
(MIP, Sysmex and Micromeritics).

\section{Results and Discussion}

\subsection{Ti-felt GDL with Ti powder loading}

Figure 1 shows SEM images of Ti-felt GDL with and without Ti powder loading. In the Ti-felt GDL with Ti powder loading, the powder did not form a layer on top of the substrate but rather was deposited into the bulk of the GDB substrate (Fig. 1B). Furthermore, the powder was relatively uniformly distributed in not only the in-plane direction but also the through-plane direction of the GDB. Figure 2 shows the effect of Ti powder loading on the pore size distribution of four cells (U1, M1, M2, and M3 cells) by plotting pore diameter versus logarithm differential volume (based on the MIP results). For the bare Ti-felt GDL of U1, the main peak pore size was 50 60 $\mu$ m, whereas for the GDL with Ti powder loading, this peak shifted to less than 50um. The structural changes in these different pore size ranges can be identified by grouping the pores in the GDL into the same categories used by Wang et al. [41]; namely, macro-pores (pore diameter more than $7 \mu \mathrm{m}$ ), meso-pores (from 0.05 to $7 \mu \mathrm{m}$ ) and micro-pores (less than $0.05 \mu \mathrm{m})$. Figure 2 shows that the volume of the meso-pores increased with increasing amount of Ti powder loading on GDL, whereas no micro-pores were generated by the Ti 
powder loading.

\subsection{Electrolysis performance}

The GDL of U1 cell was not treated with Ti-powder and PTFE, whereas the GDLs of U2, U3 were treated with 69 and $148 \mathrm{mg} / \mathrm{cm}^{3}$ of PTFE, and those of M1, M2 and M3 were loaded with 110, 200 and $300 \mathrm{mg} / \mathrm{cm}^{3}$ of Ti-powder, respectively, as well as treated with PTFE. Figure 3 shows the measured $i-V$ characteristics during the electrolysis mode for these cells. In the electrolysis mode, liquid water is supplied at the oxygen electrode as reactant fuel and humidifies the membrane. As noted in Sec. 2, liquid water is also supplied at the hydrogen electrode concerning about the safety, however, from our previous experimental study [44], it was revealed that liquid water supply at the hydrogen electrode does not cause any noticeable effect on the cell performance. Thus, for optimal electrolysis performance, both an efficient water supply and gas discharge via the oxygen-side GDL is critical. Our previous experimental study [45] reported that electrolysis performance was not noticeably affected by a change in PTFE content in the GDL, when the mean pore diameter of the oxygen-electrode GDL was less than about $50 \mu \mathrm{m}$. In contrast, that study also revealed that large oxygen bubbles from the large pores hindered the water supply due to blocking of the water 
channel. In our current study, although the porous characteristics (permeability, wettability) changed depending on the amount of Ti-powder loading on the oxygen electrode GDL, the $i-V$ characteristics were the same for the U1, M1, M2 and M3 cells (Fig. 2B). Similarly, the differences in electrolysis performance were negligible among the U1, U2 and U3 cells. The pore distribution (Fig. 2) of M1, M2 and M3 showed a decrease in the main peak in pore size from 60 to $40 \mu \mathrm{m}$ and showed a small peak in the meso-pore range (0.05-7 $\mu \mathrm{m})$. This suggests that the yield of meso-pores volume does not affect either the bubble size or flow regime, and that the maximum pore diameter of GDL, which is nearly equal to the main peak in the macro-pore region, is the determining parameter for the bubble size generated from the GDL. We discussed this speculation in another article in detail [47]. Because the change of pore size in main peak was small, the bubble size and flow regime in the flow channel must be nearly the same in all the cells studied here, and thus no noticeable difference in electrolysis performance was observed.

\subsection{Fuel cell performance}

The effect of the amount of Ti powder loading in the GDL of the oxygen electrode on fuel cell performance was evaluated here by analyzing the $i-V$ 
characteristics and overpotential. The humidification temperatures of reactant gases $\left(T_{\text {fuel }}\right)$ were set as $70^{\circ} \mathrm{C}$ and $80^{\circ} \mathrm{C}$ for relatively dry conditions $(\mathrm{RH}=66 \%)$ and fully wet condition $(\mathrm{RH}=100 \%)$, respectively.

Figure 4 shows the $i-V$ characteristics of $\mathrm{U} 1, \mathrm{U} 2$, U3 cells during fuel cell mode at $T_{\text {fuel }}=80^{\circ} \mathrm{C}$ of fully wet condition. Although all three cells had the same $\varepsilon(0.75)$, their Ti-felt GDLs were coated with different amounts of PTFE (0, 69, and $148 \mathrm{mg} / \mathrm{cm}^{3}$, respectively). U2 and U3 exhibited slightly improved fuel cell performance compared with U1. Figure 5 shows the $i-V$ characteristics of U1, M1, M2 and M3 cells during fuel cell mode at fully wet condition. The U1 cell, using bare Ti-felt as the oxygen-side GDL, showed a severe flooding problem at low $i\left(\sim 100 \mathrm{~mA} / \mathrm{cm}^{2}\right)$. In contrast, the M2 and M3 cells showed drastically improved $i-V$ characteristics, whereas the M1, U2 and U3 cells showed only slightly improved characteristics (Figs.4 and 5). These results suggest that changes in GDL properties caused by a threshold amount of Ti-powder loading (200 and $300 \mathrm{mg} / \mathrm{cm}^{3}$ ) significantly affect the cell performance. However, a small amount of Ti-powder loading in the M1 cell $\left(110 \mathrm{mg} / \mathrm{cm}^{3}\right)$ slightly improved the performance, similar to the observed improvement with PTFE content (U2, U3). To further analyze the effect of Ti-powder loading on the cell performance, we categorized the overpotentials into the three groups previously described [45]: ohmic overpotential $\left(\eta_{\text {ohm }}\right)$, 
concentration overpotential $\left(\eta_{\text {conc }}\right)$, and activation overpotential $\left(\eta_{\text {act }}\right)$. Figure 6 compares $\eta_{\text {conc }}, \eta_{\text {act }}$ and $\eta_{\text {ohm }}$ calculated from the $i-V$ curves shown in Fig. 5 . The difference in $\eta_{\text {ohm }}$ was small and the cell resistance $\left(R_{\text {cell }}\right)$ measured by the AC impedance was relatively constant throughout the entire $i$ range. The U1 cell showed a rapidly increased $\eta_{\text {conc }}$ at low $i\left(\sim 100 \mathrm{~mA} / \mathrm{cm}^{2}\right)$. M1 also showed a rapidly increasing $\eta_{\text {conc }}$ at low $i\left(\sim 150 \mathrm{~mA} / \mathrm{cm}^{2}\right)$ because the Ti-powder loading $\left(110 \mathrm{mg} / \mathrm{cm}^{3}\right)$ was not enough to prevent water flooding. In contrast, M2 and M3 showed relatively stable $\eta_{\text {conc }}$ until significantly high $i$ (500 $600 \mathrm{~mA} / \mathrm{cm}^{2}$ ). Comparison of the differences in $\eta_{\text {conc }}$ (Fig. 5) and differences in $i-V$ characteristics (Fig. 6) reveals that the modification of the pore structure caused by Ti-powder loading significantly affects the mass transport of liquid and gas through the GDL.

Figure 7 shows the $i-V$ characteristics of the U1, M1, M2 and M3 cells during fuel cell mode under the relatively dry condition $\left(\mathrm{RH}=66 \% ; T_{\text {fuel }}=70^{\circ} \mathrm{C}\right)$. For all these cells, the overall performance during fuel cell operation under this dry condition was superior to that at under the wet condition (Fig. 5). However, the Ti-powder loading had no positive effect on performance, but rather degrades slightly the performance of $\mathrm{M} 1$, M2 and M3 compared to that of U1.

The effect of Ti-powder loading on fuel cell performance can be discussed based on 
our experimental results and analysis data as follows. An increase in the amount of Ti-powder loading caused a shift in the main peak in the pore size distribution from about 60 to $40 \mu \mathrm{m}$ and generated a small peak in the meso-pore region $(0.05-7 \mu \mathrm{m})$ (Fig. 2). The amount of Ti-powder loading significantly affected the performance under fully wet condition ( $\mathrm{RH}=100 \%$ ) (Fig. 5). Based on these results, the main effects of Ti-powder loading are hydrophobicity and changes in pore size distribution (i.e., increased volume of meso-pore size). The improvement caused by the Ti-powder loading at $\mathrm{RH}=100 \%$ can be explained as follows. The hydrophobic meso-pores produced by the Ti-powder loading play an important role in gas transport, because they must be kept free from water and thus kept suitable for gas transport. The M1 cell (110mg/cm³ Ti-powder loading) was not enough to affect both the hydrophobicity and pore size distribution. The main peak pore volume of M1 cell is higher than U1 cell in the pore size distribution results (Fig. 2). Even though meso-pores volume is increased at M1, high volume of main peak pores would force to limit the performance improvement. If the Ti powder can be loaded as a micro-porous layer similar to a conventional MPL on a Ti-felt GDL substrate, we can expect further improvement under fully wet conditions. Lu et al. [48] explained that a GDL without an MPL has dynamic changing of breakthrough location from the interconnected water path. Contrary to this, a GDL with MPL has stationary 
breakthrough point, and thus, the greater part of GDL is kept dry all the time. Similar to that for the GDL without an MPL, the water path in the Ti-powder loaded GDL in this study was probably dynamic, because the Ti powder did not form a microporous sub-layer on the substrate surface but rather was deposited into the bulk of the substrate.

At the relatively dry condition $(\mathrm{RH}=66 \%)$, the opposite effect of the Ti-powder loading as that at the fully wet condition can be explained as follows. The produced water consists of liquid water and water vapor. Under the dry condition, the rate of vapor transport must be relatively greater than that of liquid transport. Even though the increased meso-pore $(0.05-7 \mu \mathrm{m})$ volume due to the Ti-powder loading on GDL must play an important role in the removal of liquid water at the fully wet condition, the Ti-powder loading under the relatively dry condition is not effective for the oxygen gas transport. The capillary barrier effect, which provides added resistance to oxygen gas diffusion, is stronger than the meso-pore $(0.05-7 \mu \mathrm{m})$ volume effect. The vapor tends to condense at lower porosity and at pathways that are narrowed due to Ti-powder loading. And then, condensed water can act as resistance to oxygen gas diffusion to the catalyst layer. Consequently, Ti-powder loading on the oxygen-electrode GDL is effective for removal of liquid water and for prevention of flooding, but not effective for vapor water 
transport and oxygen gas diffusion.

\section{Conclusions}

The effect of structural properties of Ti-felt as the oxygen-side GDL on both the fuel cell and electrolysis performance of a URFC was evaluated for Ti-felt GDLs loaded with different amounts of Ti powder.

At the electrolysis mode, the bubble size from the macro-pores (over $7 \mu \mathrm{m}$ ) is the dominant factor in electrolysis performance. Here, the measured $i-V$ characteristics remained relatively unaffected by the Ti-powder loading of the oxygen-electrode GDL, because the Ti-powder loading had a negligible effect on the bubble size.

At fuel cell mode, because a cell should be operated under high humidity conditions to maintain membrane durability, fuel cell performance of URFCs with Ti-powder loading was evaluated here based on measured $i-V$ characteristics and the analysis of overpotential at fully saturated humidity conditions $\left(T_{\text {fuel }}=80^{\circ} \mathrm{C}\right)$. In this study, the purpose of the Ti-powder loading on the oxygen-electrode GDLs was to improve the transport of liquid water and oxygen gas. Our results showed that the increased meso-pore $(0.05-7 \mu \mathrm{m})$ size volume and hydrophobicity due to the Ti-powder 
loading were significantly effective in preventing water flooding and in improving fuel cell performance under fully wet condition $(\mathrm{RH}=100 \%)$, but not under relatively dry conditions $(\mathrm{RH}=66 \%)$ due to different mass transport condition (ratio between vapor and liquid phase) of produced water. 


\section{References}

[1] T. Ioroi, T. Oku, K. Yasuda, N. Kumagai, Y. Miyazaki, J. Power Sources 124 (2003) 385-389.

[2] W. Smith, J. Power Sources 86 (2000) 74-83.

[3] S. Altmann, T. Kaz, K. A. Friedrich, J. Electrochim. Acta 56 (2011) 4287-4293.

[4] T. Ioroi, K. Yasuda, Z. Siroma, N. Fujiwara, Y. Miyazaki, J. Power Sources 112 (2002) 583-587.

[5] S. Zhigang, Y. Baolian, H. Ming, J. Power Sources 79 (1999) 82-85.

[6] U. Wittstadt, E. Wagner, T. Jungmann, J. Power Sources 145 (2005) 555-562.

[7] L. L. Swette, A. B. LaConti, S. A. McCatty, J. Power Sources 47 (1994) 343-351.

[8] T. Ioroi, N. Kitazawa, K. Yasuda, Y. Yamamoto, H. Takenaka, J. Electrochem. Soc. 147 (2000) 2018-2022.

[9] S. D. Yim, G. G. Park, Y. J. Sohn, W. Y. Lee, Y. G. Yoon, T. H. Yang, S. Um, S. P. Yu, C. S. Kim, Int. J. Hydrog. Energy 30 (2005) 1345-1350.

[10] S. Song, H. Zhang, X. Ma, Z. G. Shao, Y. Zhang, B. Yi, Electrochem. Commun. 8 (2006) 399-405.

[11] G. Chen, H. Zhang, H. Zhong, H. Ma, J. Electrochim. Acta 55 (2010) 8801-8807.

[12] H. Y. Jung, S. Y. Huang, P. Ganesan, B. N. Popov, J. Power Sources 194 (2009) 972-975.

[13] T. Sasabe, P. Deevanhxay, S. Tsushima, S. Hirai, Electrochem. Commun. 13 (2011) 638-641.

[14] S. Tsushima, S. Hirai, J. Progress in Energy and Combustion Science 37 (2011) 204-220. 
[15] Z. Zhan, C. Wang, W. Fu, M. Pan, Int. J. Hydrog. Energy (2011) in press.

[16] M. A. Hickner, N. P. Siegel, K. S. Chen, D. S. Hussey, D. L. Jacobson, M. Aril, J. Electrochem. Soc. 155 (2008) B427-B434.

[17] M. A. Hickner, N. P. Siegel, K. S. Chen, D. S. Hussey, D. L. Jacobson, M. Aril, J. Electrochem. Soc. 155 (2008) B294-B302.

[18] A. Turhan, S. Kim, M. Hatzell, M. M. Mench, J. Electrochim. Acta 55 (2010) $2734-2745$.

[19] Hua Meng, Int. J. Hydrog. Energy 34 (2009) 5488-5497.

[20] R. Wu, X. Zhu, Q. Liao, H. Wang, Y. D. Ding, J. Li, D. D. Ye, Int. J. Hydrog. Energy 35 (2010) 9134-9143.

[21] E. Nishiyama, T. Murahashi, J. Power Sources 196 (2011) 1847-1854.

[22] R. Wu, X. Zhu, Q. Liao, H. Wang, Y. D. Ding, J. Li, D. D. Ye, Int. J. Hydrog. Energy 35 (2010) 7588-7593.

[23] A. Z. Weber, J. Newman, J. Electrochem. Soc. 152 (2005) A677-A688.

[24] J. Chen, U. Matsuura, M. Hori, J. Power Sources 131 (2004) 155-161.

[25] S. Park, J. W. Lee, B. N. Popov, J. Power Sources 177 (2008) 457-463.

[26] M. Hunsom, P. Piumsomboon, K. Pruksatuorn, N. Tantavichet, S. Endoo, K. Charutavai, K. Poochinda, J. Renewable Energy 36 (2011) 369-373.

[27] P. G. Stampino, C. Cristiani, G. Dotelli, L. Omati, L. Zampori, R. Pelosato, M. Guilizzoni, J. Catalysis Today 1475 (2009) 530-535.

[28] S. Park, J. W. Lee, B. N. Popov, J. Power Sources 163 (2006) 357-363.

[29] J. M. Lamanna, S. G. Kandlikar, Int. J. Hydrog. Energy 36 (2011) 5021-5029.

[30] T. Kitahara, T. Konomi, H. Nakajima, J. Power Sources 195 (2010) 2202-2211.

[31] C. J. Tseng, S. K. Lo, J. Energy Conversion and Management 51 (2010) 677-684. 
[32] Y. T. Lee, B. S. Kim, Y. C. Kim, X. Li, J. Power Sources 196 (2011) 1940-1947.

[33] C. Lin, T. Wang, F. Ye, Y. Fang, X. Wang, Electrochem. Commun. 10 (2008) $255-258$.

[34] T. Y. Kim, S. J. Lee, H. K. Park, Int. J. Hydrog. Energy 35 (2010) 8631-8643.

[35] T. Kitahara, H. Nakajima, T. Konomi, ECS Trans. 33(1) (2010) 1089-1097.

[36] J. H. Chun, K. T. Park, D.H. Jo, J. Y. Lee, S. G. Kim, S. H. Park, E. S. Lee, J. Y. Jyoung, S. H. Kim, Int. J. Hydrog. Energy 36 (2011) 8422-8428.

[37] M. J. Ahn, Y. H. Cho, Y. H. Cho, J. H. Kim, N. G. Jung, Y. E. Sung, J. Electrochim. Acta 56 (2011) 2450-2457.

[38] K. Karan, HK. Atiyeh, A. Phoenix, E. Halliop, J. Pharoah, B. Peppley, Electrochem. Solid State Lett. 10 (2007) B34-B38.

[39] HK. Atiyeh, K. Karan, B. Peppley, A. Phoenix, E. Halliop, J. Pharoah, J. Power Sources 170 (2007) 111-121.

[40] A. Z. Weber, J. Newman, J. Electrochem. Soc. 151 (2004) A1715-A1727.

[41] X. Wang, H. Zhang, J. Zhang, H. Xu, X. Zhu, J. Chen, B. Yi, J. Power Sources 162 (2006) 474-479.

[42] J. T. Gostick, M. A. Ioannidis, M. W. Fowler, M. D. Pritzker, Electrochem. Commun. 11 (2009) 576-579.

[43] S.A. Grigoriev, P. Millet, S. S. Volobuev, V. N. Fateev, Int. J. Hydrog. Energy 34 (2009) 4968-4973.

[44] H. Ito, T. Maeda, A. Nakano, Y. Hasegawa, N. Yokoi, C. M. Hwang, M. Ishida, A. Kato, T. Yoshida, Int. J. Hydrog. Energy 35 (2010) 9550-9560.

[45] C. M. Hwang, M. Ishida, H. Ito, T. Maeda, A. Nagano,Y. Hasegawa, N. Yokoi, A. Kato, T. Yoshida, Int. J. Hydrog. Energy 36 (2011) 1740-1753. 
[46] R. Borup, J. Meyers, B. Pivovar, Y. S. Kim, R. Mukundan, N. Garland, Am. Chem. Soc. 107 (2007) 3904-3951.

[47] H. Ito, T. Maeda, A. Nakano, C. M. Hwang, M. Ishida, A. Kato, T. Yoshida, submitted to Int. J. Hydrog. Energy.

[48] Z. Lu, M. M. Daino, C. Rath, S. G. Kandlikar, Int. J. Hydrog. Energy 35 (2010) $4222-4233$. 


\section{Figure captions}

Figure 1. SEM images of (A) as-is Ti-felt GDL (Bekinit) and (B) Ti-powder loaded $\left(300 \mathrm{mg} / \mathrm{cm}^{3}\right)$ Ti-felt GDL. Ti-felt had a fiber diameter $(\phi)$ of $20 \mu \mathrm{m}$ and porosity $(\varepsilon)$ of 0.75 . Ti powder had an average diameter of $20 \mu \mathrm{m}$.

Figure 2. Effect of Ti-powder loading on the Ti-felt GDL (U1, M1, M2, and M3 cells) and pore distribution represented by pore diameter versus logarithm differential volume (based on MIP results).

Figure 3. Effect of (A) PTFE loading and (B) Ti-powder loading on current density (i) voltage $(\zeta)$ characteristics during electrolysis mode for URFCs. Cell temperature $\left(T_{\text {cell }}\right)$ was $80^{\circ} \mathrm{C}$. Cell specifications are listed in Table 1.

Figure 4. Effect of PTFE loading on current density (i) - voltage (V) characteristics during fuel cell mode under fully wet condition $(\mathrm{RH}=100 \%)$ for URFCs. Cell temperature $\left(T_{\text {cell }}\right)$ was $80^{\circ} \mathrm{C}$. Cell specifications are listed in Table 1.

Figure 5. Effect of Ti-powder loading on the current density (i) - voltage (V) characteristics during fuel cell mode under fully wet condition $(\mathrm{RH}=100 \%)$ for URFCs. Cell specifications are listed in Table 1 . Both humidification temperature $\left(T_{\text {fuel }}\right)$ and cell temperature $\left(T_{\text {cell }}\right)$ were $80^{\circ} \mathrm{C}$.

Figure 6. Effect of Ti-powder loading on current density (i) and (A) ohmic overpotential 
( $\left.\eta_{\text {ohm }}\right)$, (B) concentration overpotential ( $\eta_{\text {conc }}$ ), and (C) activation overpotential ( $\eta_{\text {act }}$ ) during fuel cell mode of URFCs. Cell specifications are listed in Table 1. Both humidification temperature $\left(T_{\text {fuel }}\right)$ and cell temperature $\left(T_{\text {cell }}\right)$ were $80^{\circ} \mathrm{C}$. Overpotentials were calculated from $i-V$ data shown in Fig. 5.

Figure 7. Effect of Ti-powder loading on current density $(i)$ - voltage (V) characteristics during fuel cell mode under relatively dry condition $(\mathrm{RH}=66 \%)$. Cell specifications are listed in Table 1. Humidification temperature $\left(T_{\text {fuel }}\right)$ was $70^{\circ} \mathrm{C}$, and the cell temperature ( $\left.T_{\text {cell }}\right)$ was $80^{\circ} \mathrm{C}$.

Table 1. Specifications of oxygen-electrode GDL for URFC performance test a). 


\section{Figure 1}

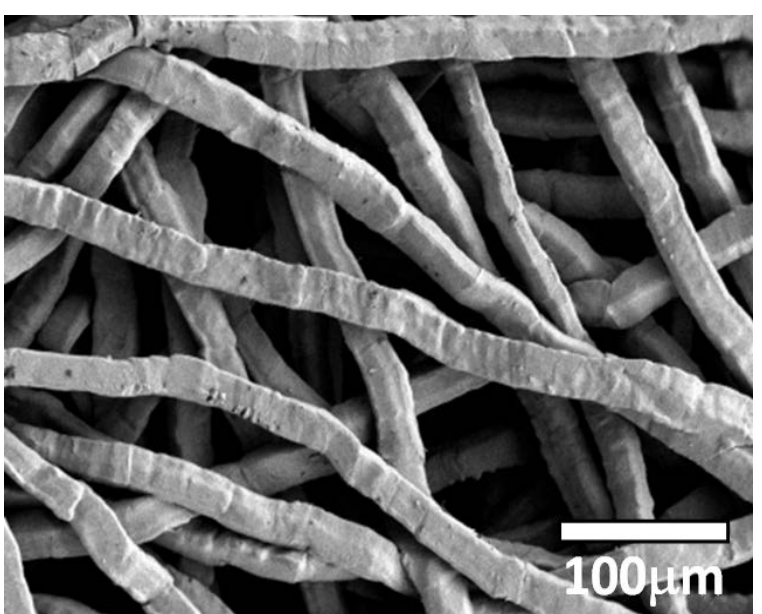

(A) Ti-felt GDL

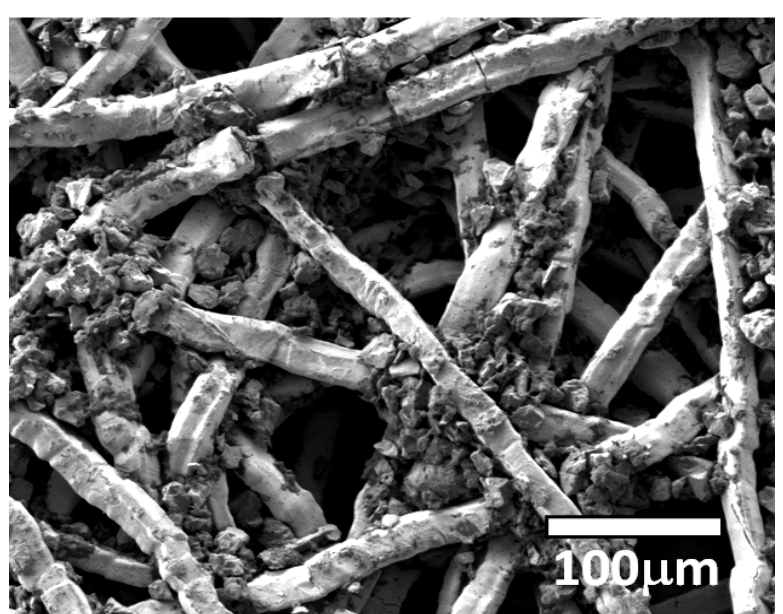

(B) Ti powder loaded Ti-felt GDL

Figure 1. SEM images of (A) original Ti-felt GDL (Bekinit) and (B) Ti-powder loaded $\left(300 \mathrm{mg} / \mathrm{cm}^{3}\right)$ Ti-felt GDL. Ti-felt had a fiber diameter of $20 \mu \mathrm{m}$ and porosity of 0.75 . The average diameter of $\mathrm{Ti}$ powder is $20 \mu \mathrm{m}$. 


\section{Figure 2}

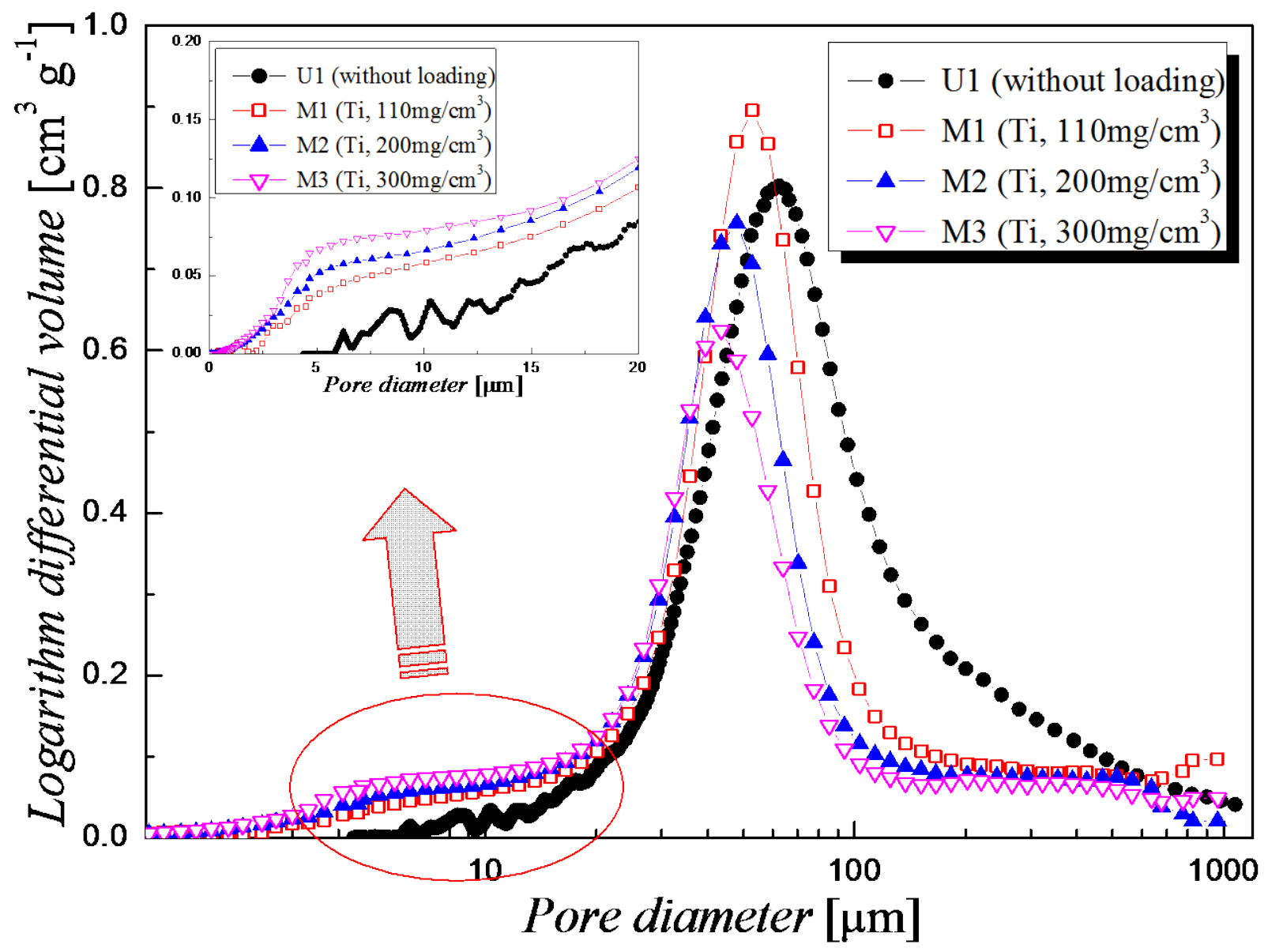

Figure 2. Effect of Ti-powder loading on the Ti-felt GDL (U1, M1, M2, and M3 cells) and Pore distribution represented by pore diameter versus logarithm differential volume (based on MIP results). 


\section{Figure 3}
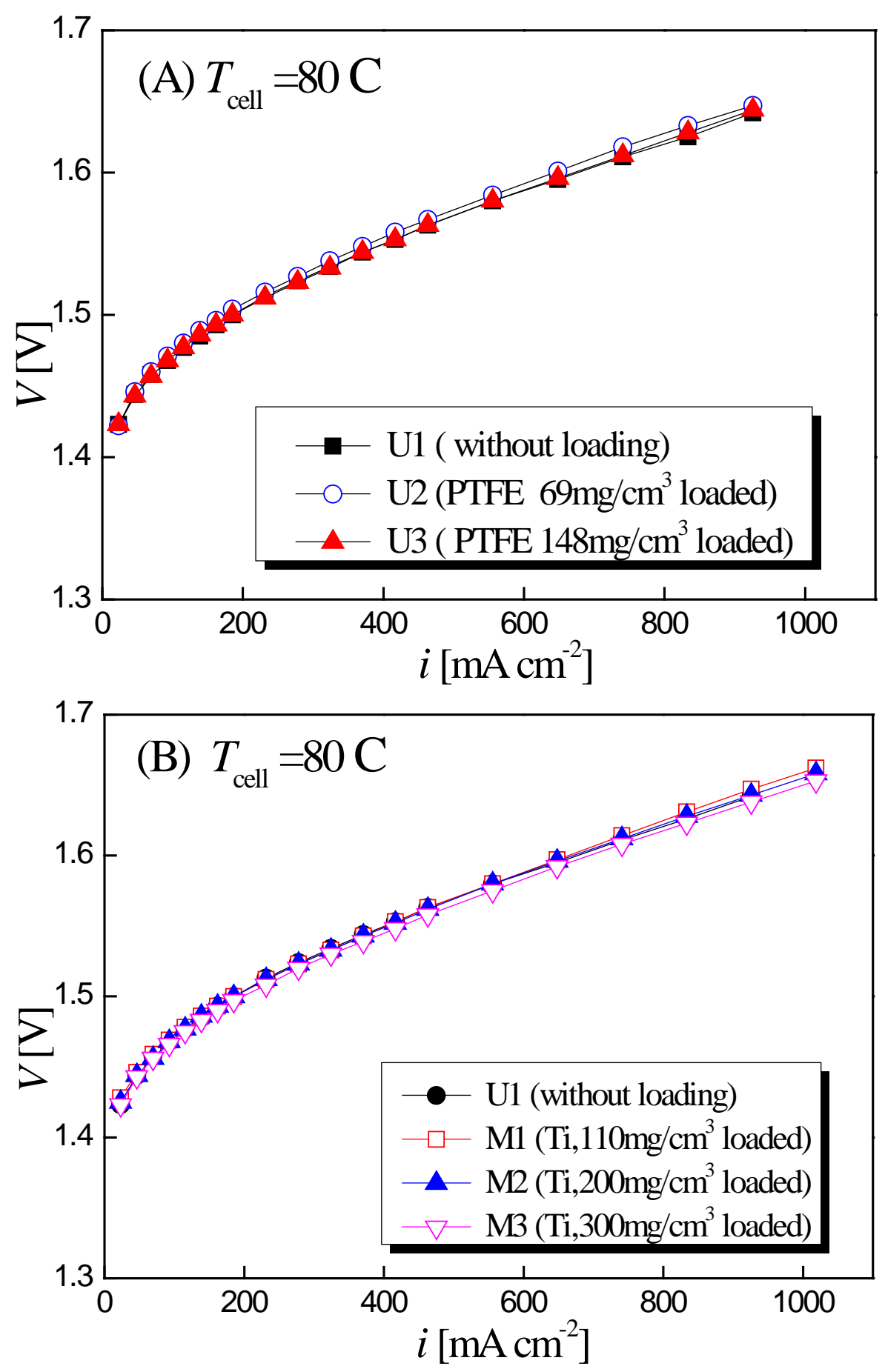

Figure 3. Effect of (A) PTFE loading and (B) Ti-powder loading on current density (i) voltage $(V)$ characteristics during electrolysis mode for URFCs. Cell temperature ( $\left.T_{\text {cell }}\right)$ was $80^{\circ} \mathrm{C}$. Cell specifications are listed in Table 1 . 
Figure 4

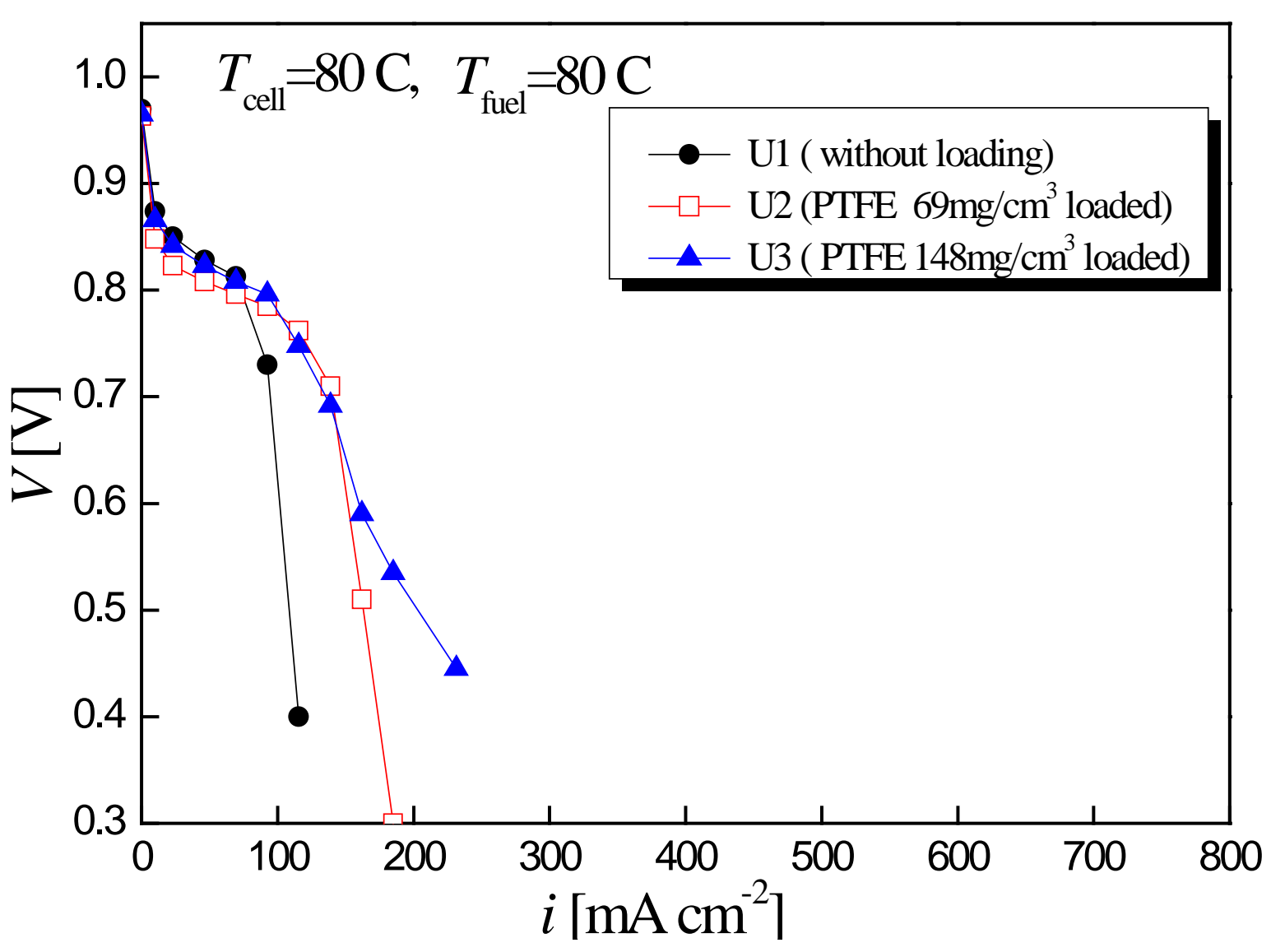

Figure 4. Effect of PTFE loading on current density (i) - voltage (V) characteristics during fuel cell mode under fully wet condition $(\mathrm{RH}=100 \%)$ for URFCs. Cell temperature $\left(T_{\text {cell }}\right)$ was $80^{\circ} \mathrm{C}$. Cell specifications are listed in Table 1 . 
Figure 5

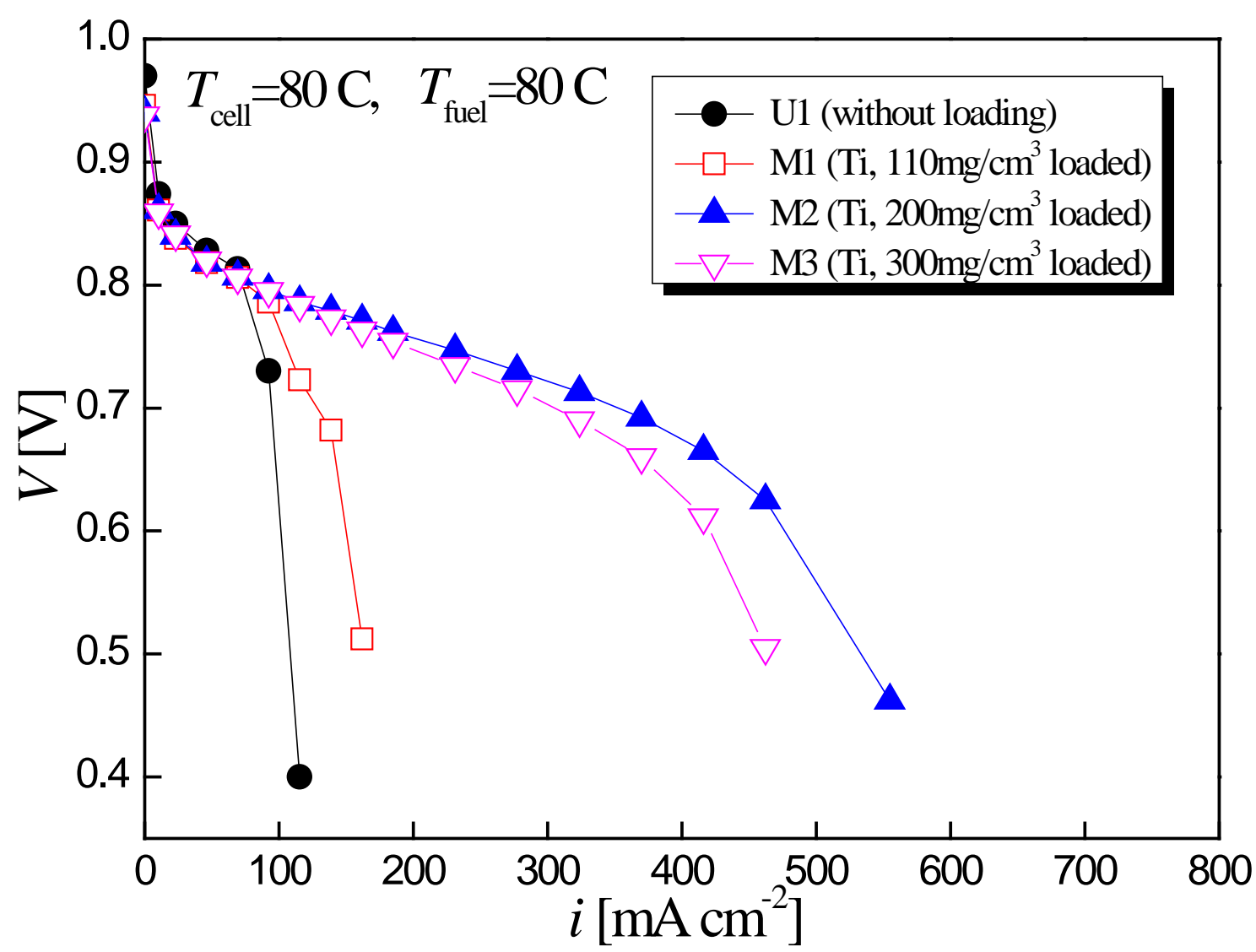

Figure 5. Effect of Ti-powder loading on the current density $(i)$ - voltage $(V)$ characteristics during fuel cell mode under fully wet condition $(\mathrm{RH}=100 \%)$ for URFCs. Cell specifications are listed in Table 1. Both humidification temperature $\left(T_{\text {fuel }}\right)$ and cell temperature $\left(T_{\text {cell }}\right)$ were $80^{\circ} \mathrm{C}$. 
Figure 6

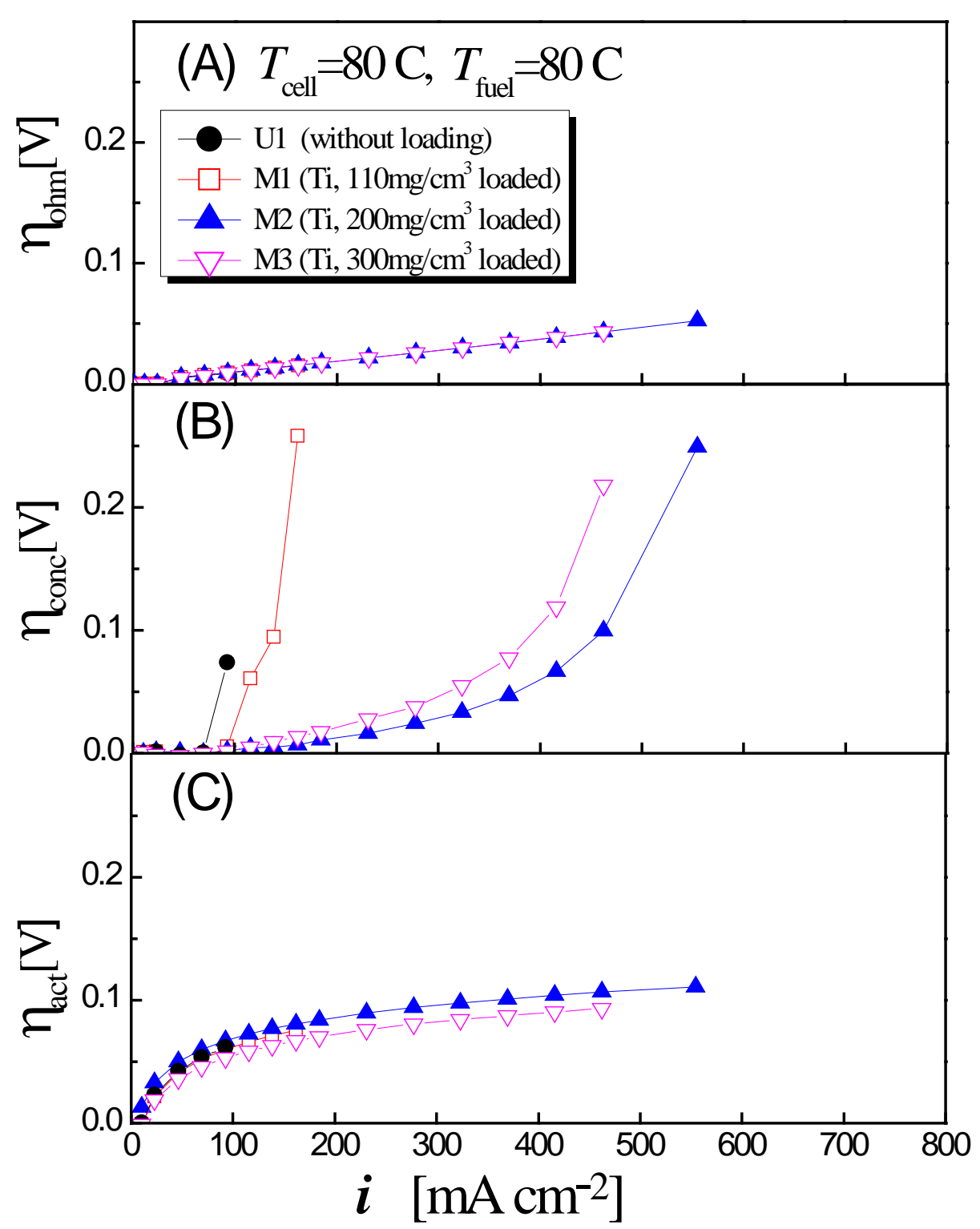

Figure 6. Effect of Ti-powder loading on current density (i) and (A) ohmic overpotential ( $\eta_{\text {ohm }}$ ), (B) concentration overpotential ( $\eta_{\text {conc }}$ ), and (C) activation overpotential ( $\eta_{\text {act }}$ ) during fuel cell mode of URFCs. Cell specifications are listed in Table 1. Both humidification temperature $\left(T_{\text {fue }}\right)$ and cell temperature $\left(T_{\text {cell }}\right)$ were $80^{\circ} \mathrm{C}$. Overpotentials were calculated from $i-V$ data shown in Fig. 5. 
Figure 7

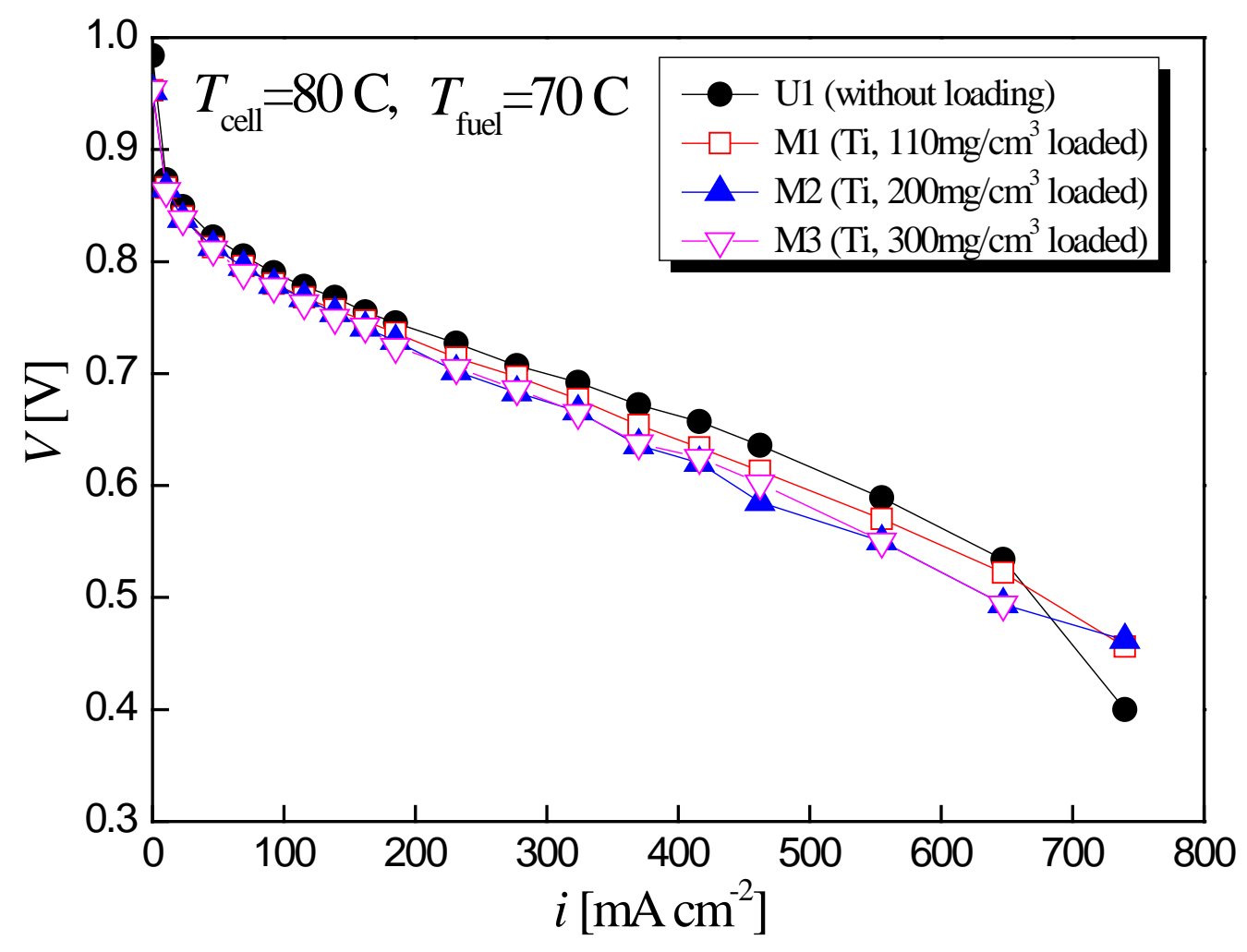

Figure 7. Effect of Ti-powder loading on current density (i) - voltage (V) characteristics during fuel cell mode under relatively dry condition $(\mathrm{RH}=66 \%)$. Cell specifications are listed in Table 1 . Humidification temperature $\left(T_{\text {fuel }}\right)$ was $70^{\circ} \mathrm{C}$, and the cell temperature $\left(T_{\text {cell }}\right)$ was $80^{\circ} \mathrm{C}$. 
Table 1. Specification of GDL at the oxygen electrode for URFC performance test a).

\begin{tabular}{ccccc}
\hline Cell & GDL $\left(\mathrm{O}_{2}\right.$ side $)$ & Porosity $(\varepsilon)$ & $\begin{array}{c}\text { PTFE } \\
\text { loading } \\
{\left[\mathrm{mg} / \mathrm{cm}^{3}\right]}\end{array}$ & $\begin{array}{c}\text { Ti powder } \\
\text { loading } \mathrm{d}) \\
{\left[\mathrm{mg} / \mathrm{cm}^{3}\right]}\end{array}$ \\
\hline U1 ${ }^{\text {b) }}$ & Ti-felt & 0.75 & - & - \\
\hline U2 & Ti-felt & 0.75 & 69 & - \\
U3 & Ti-felt & 0.75 & 148 & - \\
\hline M1 & Ti-felt + Ti powder & $0.73^{\text {c) }}$ & 1.1 & 200 \\
M2 & Ti-felt + Ti powder & $0.71^{c)}$ & 2.0 & 300 \\
M3 & Ti-felt + Ti powder & $0.68^{c)}$ & 3.0 & \\
\hline
\end{tabular}

a) Carbon paper GDL coated with PTFE (10wt\% emulsion) commonly used for hydrogen-electrode GDL.

b) Standard cell (i.e., without PTFE or Ti powder loading).

c) Calculated based on amount of Ti-powder loading.

d) Calculated based on outer geometry of GDL. 